\title{
Sistem Pendukung Keputusan Menggunakan Metode FUCOM-MOORA untuk Penentuan Maskapai Favorit
}

\author{
Gede Surya Mahendra*, Anthony Lee, Gede Dharma Sahasra Muni \\ Program Studi Teknik Informatika, STMIK STIKOM Indonesia \\ Jalan Tukad Pakerisan No 97, Denpasar, Indonesia, 80225 \\ *e-mail: gede.mahendra@stiki-indonesia.ac.id
}

(received: 13April 2021, revised: 24 Juli 2021, accepted: 1 Agustus 2021)

\begin{abstract}
Abstrak
Sejak dikeluarkannya berupa serangkaian langkah deregulasi pada tahun 1999, perkembangan industri jasa udara Indonesia semakin berkembang. Namun masih terdapat fakta bahwa banyak maskapai mengalami berbagai kendala sebelum dan selama penerbangan. Pada tahun 2021 saja, terdapat berbagai permasalahan pada pesawat maskapai mulai dari masalah mesin, kendala teknis, kerusakan ban, gangguan cockpit, hingga masalah tekanan udara. Pelanggan maskapai memiliki pertimbangan serta preferensi pribadi untuk memilih maskapai perjalanannya. Banyaknya pilihan maskapai serta banyaknya pertimbangan seringkali membingungkan pelanggan. Untuk menanggulangi hal tersebut, sistem pendukung keputusan (SPK) dapat dipergunakan untuk memberikan rekomendasi dalam memilih maskapai yang sesuai dengan pilihan pelanggan. Penelitian ini telah berhasil mengimplementasikan FUCOM-MOORA dalam penentuan maskapai favorit di Indonesia berdasarkan narasumber yang dilakukan sampling, dengan menggunakan 8 kriteria dan 6 alternatif yang diujikan. Pada perhitungan pembobotan kriteria menggunakan FUCOM menunjukkan bahwa faktor harga (C5) merupakan faktor yang paling diperhitungkan. Perhitungan menggunakan FUCOMMOORA menunjukkan bahwa Garuda Indonesia menjadi maskapai favorit di Indonesia dengan nilai preferensi sebesar 0,30204, disusul dengan Citilink menjadi maskapai favorit kedua, Batik Air menempati peringkat ketiga. Pengujian menggunakan analisis konsistensi menunjukkan bahwa Garuda Indonesia tetap stabil menjadi pilihan pertama dengan menempati 15 kali peringkat teratas dari 17 pengujian dengan rata-rata sebaran peringkat sebesar 1,23466.
\end{abstract}

Kata kunci: FUCOM, MOORA, SPK, Maskapai, Indonesia

\begin{abstract}
Since the issuance of a series of deregulation steps in 1999, the development of Indonesia's air services industry has continued to develop. However, there is still the fact that many airlines experience various problems before and during the flight. In 2021 alone, there will be various problems with airline aircraft ranging from engine problems, technical problems, tire damage, cockpit problems, to air pressure problems. Airline customers have personal considerations and preferences in choosing their travel carrier. The many choices of airlines and many considerations often confuse customers. To overcome this, a decision support system (DSS) can be used to provide recommendations in selecting airlines that are in accordance with customer preferences. This research has successfully implemented FUCOM-MOORA in determining the favorite airlines in Indonesia based on resource persons who were sampled, using 8 criteria and 6 tested alternatives. In calculating the weighting of the criteria using FUCOM, it shows that the price factor (C5) is the most calculated factor. Calculations using FUCOM-MOORA show that Garuda Indonesia is the favorite airline in Indonesia with a preference value of 0.30204, followed by Citilink being the second favorite airline, Batik Air in third place. Testing using consistency analysis shows that Garuda Indonesia remains stable as the first choice by occupying the top 15 out of 17 tests with an average ranking distribution of 1.23466.
\end{abstract}

Keywords: FUCOM, MOORA, DSS, Airlines, Indonesia 


\section{Pendahuluan}

Sejak dikeluarkannya berupa serangkaian langkah deregulasi pada tahun 1999, perkembangan industri jasa udara Indonesia semakin berkembang. Banyaknya maskapai yang beroperasi di Indonesia secara langsung membawa persaingan yang ketat. Namun masih terdapat fakta bahwa banyak maskapai mengalami berbagai kendala sebelum dan selama penerbangan. Pada tahun 2021 saja, terdapat berbagai permasalahan pada pesawat maskapai mulai dari masalah mesin, kendala teknis, kerusakan ban, gangguan cockpit, hingga masalah tekanan udara [1]. Kondisi COVID-19 juga telah menghambat kondisi bisnis maskapai penerbangan. Produsen pesawat Airbus mengumumkan bahwa akibat pandemi, kerugiannya mencapai 18,8 triliun rupiah[2]. Tidak hanya terdampak kepada perusahaan, sebanyak 25 juta orang menganggur akibat COVID-19, dan angka-angka ini terus meningkat mengikuti grafik durasi pandemi[3]. Peningkatan layanan maskapai terus dilakukan, terutama di masa pandemi. Salah satunya dengan memberikan layanan free rapid test antigen yang dilaksanakan oleh Garuda Indonesia, Lion Air, Batik Air, Nam Air serta Sriwijaya Air[4].

Semakin baik standar kualitas layanan dari maskapai yang dipilih, semakin besar pula minat calon penumpang untuk menggunakan layanannya[5]. TripAdvisor merupakan salah satu situs yang bergerak di bidang booking online dan memberikan informasi berbagai akomodasi di berbagai daerah di belahan dunia[6]. Pelanggan TripAdvisor memiliki fitur yang memungkinkan untuk menilai akomodasi yang digunakan secara online. Rating tersebut dapat digunakan oleh semua pihak berdampak terhadap peningkatkan kualitas layanan dan memberikan informasi terkait akomodasi unggulan tersebut. Meskipun demikian, pelanggan maskapai memiliki pertimbangan serta preferensi pribadi untuk memilih maskapai perjalanannya. Banyaknya pilihan maskapai serta banyaknya pertimbangan seringkali membingungkan pelanggan. Untuk menanggulangi hal tersebut, sistem pendukung keputusan (SPK) dapat dipergunakan untuk memberikan rekomendasi dalam memilih maskapai yang sesuai dengan pilihan pelanggan. SPK adalah sistem efektif yang menggunakan aturan keputusan, model analisis, basis data komprehensif, dan pengetahuan pembuat keputusan untuk membantu membuat keputusan yang kompleks [7]-[9].

Dalam penelitian ini metode yang digunakan adalah kombinasi dari FUCOM-MOORA. Kombinasi metode tersebut dipilih karena FUCOM memiliki keunggulan berupa algoritma yang lebih sederhana, hasil pembobotan kriteria yang lebih kredibel, serta proses perbandingan antar kriteria yang lebih sedikit dan memungkinkan untuk menggunakan integer, nilai desimal atau skala yang sudah ditentukan sebelumnya sehingga lebih fleksibel dibandingkan dengan AHP ataupun BWM[10][12]. MOORA memiliki tingkat fleksibilitas dan kemudahan untuk dipahami dalam memisahkan subjektif dari suatu proses evaluasi ke dalam kriteria bobot keputusan dengan beberapa atribut pengambilan keputusan [13]-[16]. Namun demikian belum ada analisis komprehensif mengenai bagaimana perbandingan antar kombinasi metode tersebut dari sisi analisis konsistensi, beberapa pengambil keputusan yang memiliki pembobotan berbeda, dan bagaimana pengujian menggunakan analisis konsistensinya. Maka dari itu, penelitian ini bertujuan untuk melakukan perhitungan kombinasi metode FUCOM- MOORA dan menganalisis konsistensi kombinasi metode tersebut. Urgensi dari penelitian ini apabila tidak direalisasikan akan mengakibatkan pengembangan SPK metode ini menjadi stagnan dan hanya mencapai tahap perhitungan manual dan perancangan saja, hingga dapat menghambat inovasi dibidang SPK.

\section{Tinjauan Literatur}

Maskapai penerbangan atau badan usaha angkutan udara adalah badan usaha angkutan udara adalah badan usaha milik negara, badan usaha milik daerah, atau badan hukum Indonesia berben-tuk perseroan terbatas, yang kegiatan utamanya mengoperasikan pesawat udara un-tuk digunakan mengangkut penumpang, kargo, dan/atau pos dengan memungut pembayaran, sesuai dengan penjelasan Peraturan Menteri Perhubungan Nomor PM 77 Tahun 2011, Pasal 1 Ayat 5 [17]. Angkutan udara niaga berjadwal adalah angkutan udara niaga yang dilaksanakan pada rute dan jadwal penerbangan yang tetap dan teratur dengan tarif tertentu dan dipublikasikan [18]. Perusahaan yang termasuk dalam maskapai penerbangan berjadwal di Indonesia adalah Aviastar, Batik Air, Citilink, Garuda Indonesia, Indonesia AirAsia, Indonesia Metro Aviation, Kalstar Aviation, Lion Air, NAM Air, Sriwijaya Air, Susi Air, TransNusa, Wings Air, dan Xpress Air. 
Full Consistency Method (FUCOM) yang merupakan bagian dari MCDM. FUCOM dikembangkan oleh Dragan Pamučar, Željko Stević serta Siniša Sremac pada tahun 2018 dan dikembangkan berdasarkan prinsip perbandingan berpasangan dan validasi dari hasil deviasi dari konsistensi maksimum (deviation from full consistency/ DFC) [19]. Selain memiliki jumlah kriteria perbandingan berpasangan yang sedikit, FUCOM memiliki kemampuan untuk memvalidasi hasil dengan mendefinisikan deviasi dari konsistensi maksimum perbandingan dan menghargai transitivitas (pelengkap) dalam kriteria perbandingan berpasangan. FUCOM juga mengakomodasi pengaruh subjektif dari penentu keputusan terhadap nilai akhir bobot kriteria. Hal ini mengacu pada langkah pertama dan kedua pada FUCOM, dimana penentu keputusan memberikan peringkat kriteria berdasarkan preferensi pribadi mereka dan melakukan perbandingan berpasangan dengan memberikan ranking pada kriteria yang telah ditentukan[20]. Berikut ini merupakan prosedur untuk mendapatkan pembobotan kriteria menggunakan FUCOM. Pada langkah pertama, kriteria dari kumpulan kriteria evaluasi yang telah ditentukan dan diberi peringkat. Pemeringkatan dilakukan sesuai dengan kesesuaian kriteria, yaitu mulai dari kriteria yang diharapkan memiliki bobot koefisien paling tinggi hingga ke kriteria paling tidak signifikan. Dengan demikian, kriteria yang diurutkan sesuai dengan nilai yang diharapkan dari koefisien bobot diperoleh [21]:

$C_{j(1)}>C_{j(2)}>\cdots>C_{j(k)}$

Pada langkah kedua, perbandingan kriteria peringkat dilakukan perhitungan prioritas komparatif $\left(\left(\varphi_{\frac{k}{k+1}}\right), k=1,2, \ldots, n\right.$; di mana $k$ adalah peringkat kriteria) dengan menggunakan formula:

$\frac{w_{k}}{w_{k+1}}=\varphi_{k /(k+1)}$

Sedangkan transivitas matematis dari prioritas komparatif dihitung dengan menggunakan formula:

$\frac{w_{k}}{w_{k+2}}=\varphi_{k /(k+1)} \times \varphi_{(k+1) /(k+2)}$

Pada langkah ketiga, nilai akhir dari koefisien bobot kriteria evaluasi dihitung menggunakan fungsi minimasi dengan formula:

$\min X$

s.t.

$$
\begin{aligned}
& \left|\frac{w_{j(k)}}{w_{j(k+1)}}-\varphi_{k /(k+1)}\right| \leq \chi, \forall j \\
& \left|\frac{w_{j(k)}}{w_{j(k+2)}}-\varphi_{k /(k+1)} \otimes \varphi_{(k+1) /(k+2)}\right| \leq \chi, \forall j \\
& \sum_{j=1}^{n} w_{j}=1, \forall j \\
& w_{j} \geq 0, \forall j
\end{aligned}
$$

Metode Multi-Objective Optimization on the basis of Ratio Analysis (MOORA) digunakan sebagai salah satu penentuan perangkingan dalam penentuan ekowisata pedesaan. Metode MOORA adalah sistem multi objektif yang mengoptimalkan dua atau lebih atribut yang saling bertentangan secara bersamaan, yang diperkenalkan oleh Brauers dan Zavadkas[22]. Metode ini pertama kali digunakan oleh Braurers pada tahun 2004 dalam suatu pengambilan dengan multi-kriteria, yang banyak diaplikasikan dalam berbagai bidang seperti manajemen, bangunan, kontraktor, desain jalan, dan ekonomi. Pendekatan yang dilakukan MOORA didefinisikan sebagai suatu proses secara bersamaan guna mengoptimalkan dua atau lebih yang saling bertentangan pada beberapa kendala. Metode MOORA memiliki fleksibilitas dan kemudahan untuk dipahami dan dipisahkan bagian subjektif dari suatu proses evaluasi ke dalam kriteria bobot keputusan dengan beberapa atribut pengambil keputusan[23]. Nilai preferensi menggunakan MOORA dapat dihitung dengan persamaan sebagai berikut [24]:

$$
Y i=\sum_{j=1}^{g} W_{j} X^{*}{ }_{i j}-\sum_{j=g+1}^{n} W_{j} X^{*}{ }_{i j}
$$




\section{Metode Penelitian}

Metode penelitian yang digunakan dalam penelitian ini mengikuti tahapan model Cross Industry Standard Process for Data Mining (CRISP-DM)[25]-[28]. Framework ini diharapkan mampu untuk menganalisis permasalahan bisnis dan kondisi yang sedang terjadi, memberikan transformasi data yang sesuai hingga memberikan model yang dapat menilai efektivitas dan mendokumentasikan hasil yang didapatkan. Fase model proses CRISP-DM dapat dilihat pada Gambar 1.

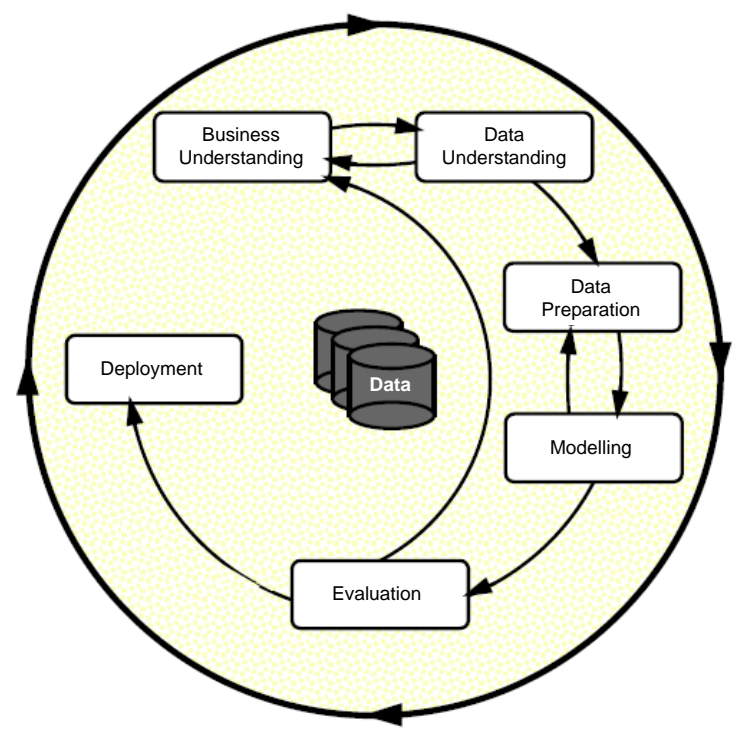

Gambar 1. Fase Model Proses CRISP-DM

Tahap pertama adalah tahap business understanding dimana digunakan untuk menentukan tujuan bisnis, melakukan analisis situasi bisnis, hingga penentuan tujuan dari SPK. Tahap ini dilakukan analisis dari hasil observasi, wawancara dan dokumen pendukung tujuan dan hasil penelitian. TripAdvisor merupakan situs yang memberikan review akomodasi perjalanan dan wisata, yang salah satunya adalah review mengenai maskapai di Indonesia. Pada TripAdvisor hanya memberikan paparan nilai tanpa mempertimbangkan preferensi dari konsumen. Masing-masing konsumen memiliki pertimbangannya sendiri dan terdapat banyak pilihan maskapai di Indonesia yang memiliki kebijakan dan standar kualitas layanan yang mirip, sering membingungkan konsumen. Pada penelitian ini akan mengambil data pada TripAdvisor sebagai data alternatif dan menggunakan 3 narasumber untuk memberikan preferensi pemilihan maskapai. Metode yang digunakan adalah kombinasi FUCOM-MOORA. Contoh review maskapai pada TripAdvisor dapat dilihat pada Gambar 2. 


\section{Overview}

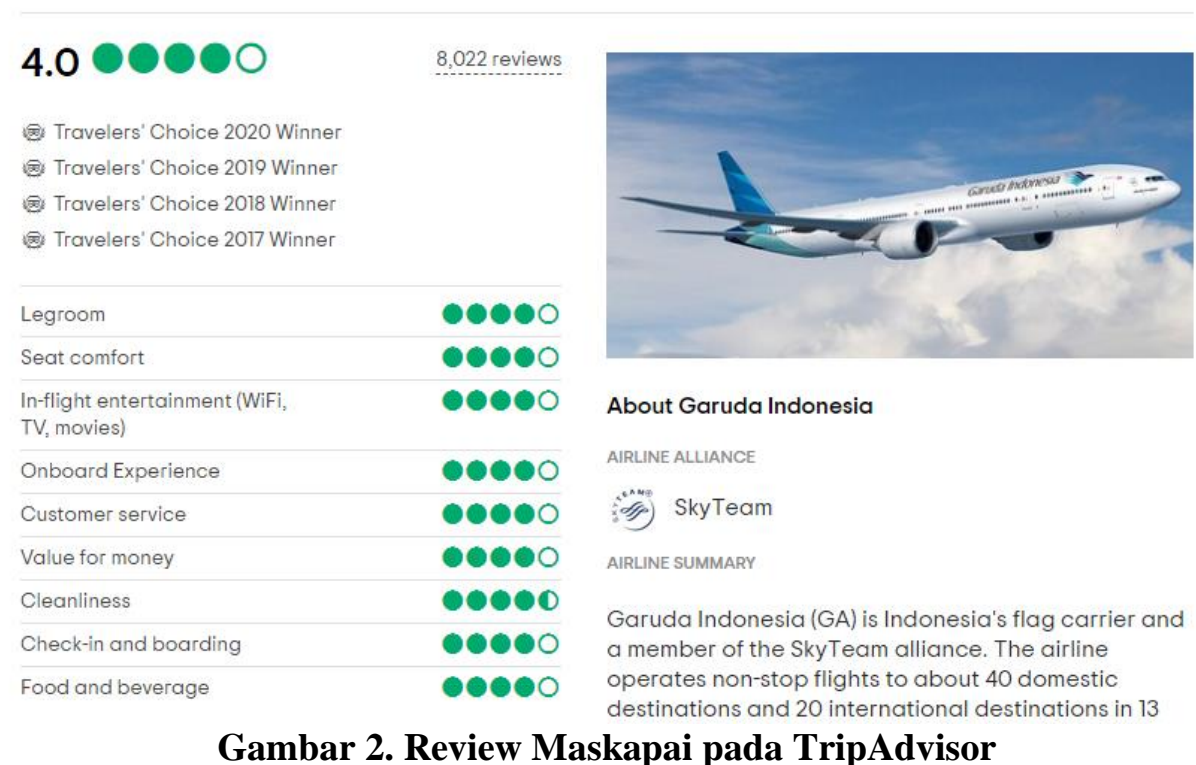

Selanjutnya terdapat tahap data understanding, untuk pengumpulan data, kemudian melakukan analisa data serta melakukan evaluasi kualitas data yang digunakan dalam penelitian. Untuk dapat memberikan rekomendasi pada konsumen, perlu mendapatkan data kriteria dan alternatif yang sesuai. Kriteria yang digunakan dalam penelitian ini meliputi kenyamanan (legroom \& seat comfort - C1), hiburan (in-flight entertainment - C2), pengalaman terbang (on board experience - C3), pelayanan pelanggan (customer service - C4), harga (pricing - C5), kebersihan (cleanliness - C6), fasilitas check-in (check in and boarding - C7), serta hidangan (food and baverages - C8). Untuk alternatif yang digunakan adalah maskapai niaga berjadwal di Indonesia sebanyak 6 perusahaan maskapai, yaitu Batik Air, Citilink, Garuda Indonesia, Indonesia AirAsia, Lion Air dan NAM Air.

Dalam tahapan selanjutnya yakni tahap data preparation meliputi pemilihan data yang akan digunakan dan data yang akan dikeluarkan untuk dimasukkan dalam perhitungan SPK. Dalam tahap ini juga dilakukan data cleaning untuk memperbaiki, menghapus atau mengabaikan noise pada data. Ketiga narasumber akan melakukan pembobotan kriteria menggunakan FUCOM. Data maskapai sebagai alternatif akan dilakukan penilaian berdasarkan kriteria yang telah ditentukan sebelumnya.

Merujuk pada tahap business understanding telah dipilih tools, teknik ataupun metode yang akan digunakan dalam penelitian ini adalah FUCOM-MOORA untuk penentuan maskapai favorit di Indonesia. Pada tahap modeling ini akan dijelaskan tata cara mengenai penggunaan metode tersebut. Sebelum melanjutkan penelitian dapat melakukan test design dengan data sementara untuk membuktikan metode tersebut dapat digunakan. Flowchart penggunaan metode dapat dilihat pada Gambar 3. 


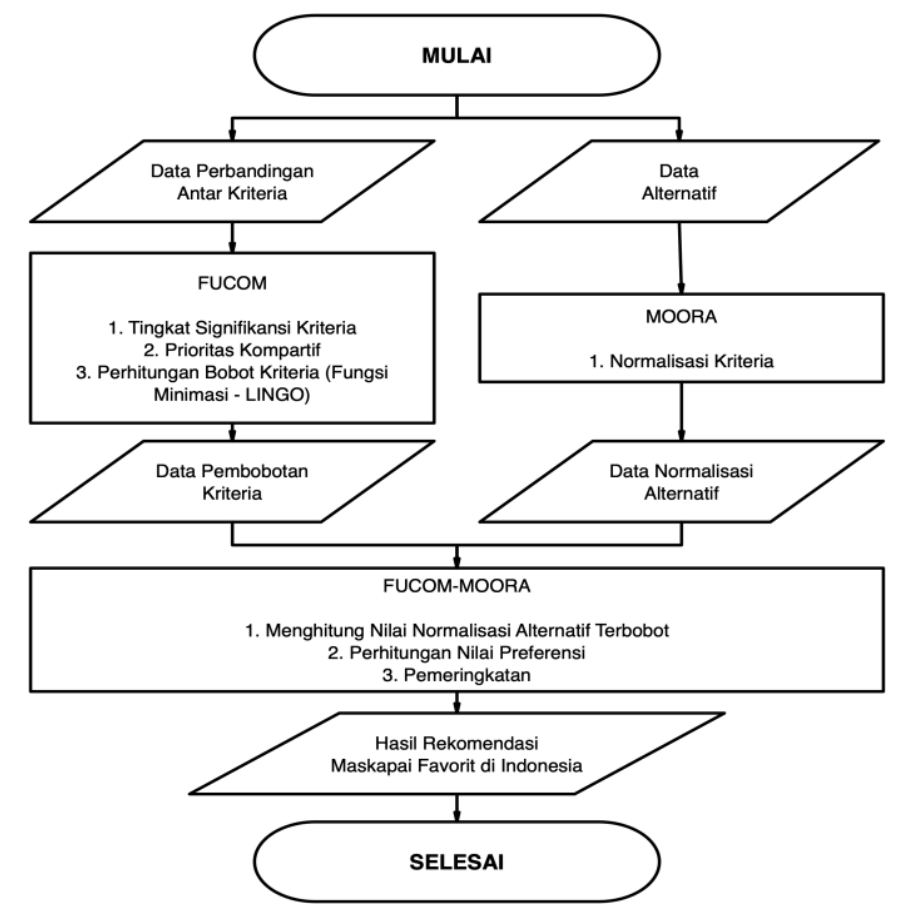

\section{Gambar 3. Flowchart Penggunaan Metode FUCOM-MOORA}

Langkah pertama adalah persiapan data perbandingan antar kriteria yang bersumber dari decision maker sebagai narasumber, dan data alternatif yang berasal dari data maskapai pada TripAdvisor OJT. Dengan menggunakan metode FUCOM, untuk menentukan data pembobotan kriteria, dimulai dari memberikan tingkat signifikansi kriteria, prioritas komparatif dan perhitungan koefesien bobot kriteria dengan fungsi minimasi menggunakan LINGO. Selanjutnya, data alternatif dilakukan normalisasi menggunakan metode MOORA sehingga menghasilkan data normalisasi alternatif. Data pembobotan kriteria menggunakan metode FUCOM dan data normalisasi alternatif menggunakan metode MOORA akan dilakukan perhitungan normalisasi terbobot dan menghitung nilai preferensi dan akan menghasilkan nilai preferensi yang dapat dilakukan perangkingan untuk dapat menentukan maskapai favorit di Indonesia. Nilai preferensi yang lebih tinggi merupakan rekomendasi maskapai yang lebih baik.

Tahap evaluation dilakukan pengujian baik pada hasil rekomendasi dari SPK maupun kinerja dari metode yang dipergunakan. Analisis konsistensi digunakan untuk mendapatkan seberapa konsisten metode FUCOM-MOORA dengan kondisi lower is better. Tahap terakhir adalah deployment, dimana dilakukan perencanaan deployment berdasarkan evaluasi yang telah dilakukan sebelumnya. Apabila hasil uji menunjukkan hasil yang baik, maka dapat direncakan deployment selanjutnya. Selain merencanakan deployment juga dapat direncanakan mengenai rencana monitoring dan maintenance hingga menghasilkan final report dan publikasi ilmiah terkait hasil penelitian.

\section{Hasil dan Pembahasan}

Untuk dapat melakukan perhitungan menggunakan metode FUCOM-MOORA, sebelumnya dilakukan pembobotan kriteria penentuan maskapai favorit berdasarkan data kuisioner dari narasumber yang telah paham dengan baik mengenai penggunaan maskapai secara aktif, yang ditransformasikan dalam metode FUCOM sebagai perbandingan antar kriteria dan data maskapai digunakan sebagai data alternatif. Jumlah narasumber yang digunakan untuk melakukan perbandingan antar kriteria untuk menghasilkan pembobotan kriteria sebanyak 3 orang, dan jumlah maskapai yang digunakan adalah 6 perusahaan maskapai.

Menggunakan metode FUCOM, ketiga narasumber memberikan penilaian pembobotan kriteria dengan cara memberikan pemeringkatan signifikansi kriteria, dan kemudian dilakukan perhitungan rasio koefesien dan transivitas matematis. Narasumber memilih kriteria yang paling disukai dan memberikan nilai 1 , dan diberikan nilai yang sama dengan sebelumnya atau diberikan penambahan nilai secara ordinal atau desimal pada kriteria yang disukai selanjutnya hingga akhir, sehingga 
pembobotan bernilai lower is better. Pembobotan ketiga narasumber terhadap masing-masing kriteria dapat dilihat pada Tabel 1.

Tabel 1. Pembobotan Kriteria Berdasarkan Ketiga Narasumber

\begin{tabular}{lcccccccc}
\hline Kriteria & C1 & C2 & C3 & C4 & C5 & C6 & C7 & C8 \\
\hline Pembobotan Narasumber 1 (NS1) & 1,1 & 1,9 & 1,5 & 1,6 & 1,0 & 1,4 & 2,1 & 2,5 \\
Pembobotan Narasumber 2 (NS2) & 1,0 & 2,0 & 1,8 & 1,4 & 1,2 & 1,6 & 2,2 & 2,5 \\
Pembobotan Narasumber 3 (NS3) & 1,5 & 1,1 & 1,9 & 2,4 & 1,0 & 1,7 & 1,3 & 2,1 \\
\hline
\end{tabular}

Selanjutnya perhitungan difokuskan pada Narasumber 1 (NS1) dan perhitungan pada narasumber lainnya mengikuti dengan perhitungan NS1. Pembobotan NS1 dilakukan pengurutan dari pembobotan terkecil hingga terbesar. Selanjutnya dilakukan perhitungan perhitungan prioritas komparatif yang nilainya merupakan rasio koefesien bobot dan juga perhitungan transivitas matematis berdasarkan rasio koefesien bobot. Pengurutuan Pembobotan Kriteria pada NS 1 ditampilkan pada Tabel 2.

Tabel 2. Pengurutan Pembobotan Kriteria Berdasarkan Narasumber 1

\begin{tabular}{lcccccccc}
\hline Kriteria & C5 & C1 & C6 & C3 & C4 & C2 & C7 & C8 \\
\hline Pembobotan NS 1 & 1,0 & 1,1 & 1,4 & 1,5 & 1,6 & 1,9 & 2,1 & 2,5 \\
\hline
\end{tabular}

Perhitungan prioritas komparatif dan rasio koefesien bobot pada NS1, dihitung menggunakan langkah-langkah sebagai berikut.

$$
\begin{aligned}
& \frac{w_{k}}{w_{k+1}}=\varphi_{k /(k+1)} \\
& \varphi_{C 5 / C 1}=1,1 / 1,0=1,10000 ; w 5 / w 1=1,10000 ; \quad \varphi_{C 1 / C 6}=1,4 / 1,1=1,27273 ; w 1 / w 6=1,27273 \\
& \varphi_{C 6 / C 3}=1,5 / 1,4=1,07143 ; w 6 / w 3=1,07143 ; \quad \varphi_{C 3 / C 4}=1,6 / 1,5=1,06667 ; w 3 / w 4=1,06667 \\
& \varphi_{C 4 / C 2}=1,9 / 1,6=1,18750 ; w^{4} /{ }_{w 2}=1,18750 ; \quad \varphi_{C 2 / C 7}=2,1 / 1,9=1,10526 ; w 2 /{ }_{w 7}=1,10526 \\
& \varphi_{C 7 / C 8}=2,5 / 2,1=1,19048 ; w 7 / w 8=1,19048
\end{aligned}
$$

Perhitungan transivitas matematis dari hasil perhitungan rasio koefesien bobot pada NS1, dihitung menggunakan langkah-langkah sebagai berikut.

$$
\frac{w_{k}}{w_{k+2}}=\varphi_{k /(k+1)} \times \varphi_{(k+1) /(k+2)}
$$

$$
\begin{array}{llrl}
w 5 / w 6 & =1,10000 \times 1,27273=1,40000 ; & & w 3 / w 2=1,27273 \times 1,07143=1,36364 \\
w 1 / w 3=1,07143 \times 1,06667=1,14286 ; & w 4 / w 7=1,06667 \times 1,18750=1,26667 \\
w 6 / w 4=1,18750 \times 1,10526=1,31250 ; & w 2 / w 8=1,10526 \times 1,19048=1,31579
\end{array}
$$

Hasil akhir dari pemodelan matematika untuk menentukan koefisien bobot kriteria evaluasi pada narasumber 1 adalah sebagai berikut.

$$
\begin{aligned}
& \min \chi \\
& \text { s.t. } \\
& \qquad \begin{array}{l}
\left|\frac{w_{5}}{w_{1}}-1,10000\right| \leq \chi,\left|\frac{w_{1}}{w_{6}}-1,27273\right| \leq \chi,\left|\frac{w_{6}}{w_{3}}-1,07143\right| \leq \chi,\left|\frac{w_{3}}{w_{4}}-1,06667\right| \leq \chi,\left|\frac{w_{4}}{w_{2}}-1,18750\right| \leq \\
\quad \chi,\left|\frac{w_{2}}{w_{7}}-1,10526\right| \leq \chi,\left|\frac{w_{7}}{w_{8}}-1,19048\right| \leq \chi, \\
\left|\frac{w_{5}}{w_{6}}-1,40000\right| \leq \chi,\left|\frac{w_{3}}{w_{2}}-1,36364\right| \leq \chi,\left|\frac{w_{1}}{w_{3}}-1,14286\right| \leq \chi,\left|\frac{w_{4}}{w_{7}}-1,26667\right| \leq \chi,\left|\frac{w_{6}}{w_{4}}-1,31250\right| \leq \\
\quad \chi,\left|\frac{w_{2}}{w_{8}}-1,31579\right| \leq \chi, \\
\sum_{j=1}^{8} w_{j}=1 \\
w_{j} \geq 0, \forall j
\end{array}
\end{aligned}
$$


Kemudian pemodelan matematika yang didapat diselesaikan menggunakan bantuan program aplikasi LINGO untuk melakukan fungsi minimasi. Notasi dan hasil fungsi minimasi untuk mencari koefisien bobot kriteria evaluasi FUCOM menggunakan LINGO dapat dilihat pada Gambar 4.

\begin{tabular}{|c|c|c|c|}
\hline Lingo Model - Narasumber 1 - Case 1.Ing & \multicolumn{3}{|c|}{ X? Solution Report - Narasumber 1 - Case 1. Ing } \\
\hline 1 MIN=epsilon; & \multirow{2}{*}{$\begin{array}{r}\text { Variable } \\
\text { EPSILON }\end{array}$} & \multirow{2}{*}{$\begin{array}{c}\text { Value } \\
0.1138862 \mathrm{E}-05\end{array}$} & \multirow{2}{*}{$\begin{array}{r}\text { Reduced Cost } \\
0.000000\end{array}$} \\
\hline 2 AABS (w5/w1-1.10000)=epsilon: & & & \\
\hline 3 aABS (w1/w6-1.27273)=epsilon: & W5 & 0.1880568 & 0.000000 \\
\hline 4 aABS $(w 6 / w 3-1.07143)=e p s i l o n ;$ & W1 & 0.1709609 & 0.000000 \\
\hline 5 AABS $(W 3 / W 4-1.06667)=e n s j l o n ;$ & W6 & 0.1343262 & 0.000000 \\
\hline 5 बABS (w3/w4-1.0666/) =epsilon; & W3 & 0.1253711 & 0.000000 \\
\hline 6 QABS $(w 4 / w 2-1.18750)=e p s i l o n ;$ & W4 & 0.1175351 & 0.000000 \\
\hline 7 @ABS (w2/w7-1.10526)=epsilon; & W2 & $0.9897686 \mathrm{E}-01$ & 0.000000 \\
\hline 8 @ABS $(w 7 / w 8-1.19048)=e p s i l o n ;$ & W7 & $0.8955066 \mathrm{E}-01$ & 0.000000 \\
\hline 9 & W8 & $0.7522238 \mathrm{E}-01$ & 0.000000 \\
\hline 10 aABS $(w 5 / w 6-1.40000)=e p s i l o n ;$ & & & \\
\hline $\begin{array}{l}11 \text { @ABS }(w 1 / w 3-1.36364)=e p s i l o n ; \\
12 \text { बABS }(w 6 / w 4-1.14286)=e p s i l o n ;\end{array}$ & & & \\
\hline 13 @ABS (w3/w2-1.26667) =epsilon; & & & \\
\hline 14 @ABS (w4/w7-1.31250)=epsilon; & & & \\
\hline 15 @ABS (w2/w8-1.31579)=epsilon; & & & \\
\hline & & & \\
\hline $\begin{array}{l}17 w 1+w 2+w 3+w 4+w 5+w 6+w 7+w 8=1 ; \\
18 w 1>=0 ; w 2>=0 ; w 3>=0 ; w 4>=0 ; w 5>=0 ; w 6>=0 ; w 7>=0 ; w 8>=0 ;\end{array}$ & & & \\
\hline
\end{tabular}

\section{Gambar 4. Notasi dan Hasil Fungsi Minimasi Untuk Mencari Koefisien Bobot Kriteria Evaluasi FUCOM Menggunakan LINGO}

Untuk menemukan rata-rata terbobot dari semua narasumber, perhitungan geometric mean (GeoMean) dilakukan berdasarkan pembobotan kriteria seluruh narasumber, yang hasilnya disajikan pada tabel 3. Pembobotan yang akan digunakan adalah hasil normalisasi dari GeoMean dari seluruh narasumber. Berdasarkan pembobotan kriteria dari seluruh narasumber, ditentukan bahwa faktor harga (C5) yang mencapai $17 \%$ merupakan faktor yang menjadi focus utama pemilihan maskapai disusul dengan kenyamanan (C1) yang mencapai 16\%, dan faktor kebersihan (C6) dan pelayanan pelanggan (C4) menjadi faktor terbesar selanjutnya yang mencapai sekitar $12 \%$.

Tabel 3. Koefisien Bobot Kriteria Evaluasi Narasumber dan Geometric Mean

\begin{tabular}{llllllllll}
\hline Kriteria & C1 & C2 & C3 & C4 & C5 & C6 & C7 & C8 & SUM \\
\hline NS1 & 0,17096 & 0,09898 & 0,12537 & 0,11754 & 0,18806 & 0,13433 & 0,08955 & 0,07522 & 1 \\
NS2 & 0,17997 & 0,10587 & 0,11248 & 0,13844 & 0,14998 & 0,12855 & 0,09472 & 0,08999 & 1 \\
NS3 & 0,12855 & 0,14998 & 0,09472 & 0,10587 & 0,17997 & 0,11248 & 0,13844 & 0,08999 & 1 \\
GeoMean & 0,15815 & 0,11626 & 0,11013 & 0,11988 & 0,17186 & 0,12477 & 0,10550 & 0,08477 & 0,99132 \\
Normalisasi & 0,15953 & 0,11728 & 0,11110 & 0,12093 & 0,17337 & 0,12586 & 0,10643 & 0,08551 & 1 \\
GeoMean & & & & & & & & & \\
\hline
\end{tabular}

Setelah mendapatkan pembobotan kriteria menggunakan FUCOM, selanjutnya dapat menghitung nilai preferensi menggunakan MOORA. Pada garis besarnya, dalam perhitungan nilai preferensi dimulai dari normalisasi nilai alternatif, perhitungan normalisasi alternatif terbobot, menghitung nilai preferensi dan pemeringkatan. Data alternatif maskapai yang digunakan pada perhitungan ini ditampilkan pada Tabel 4.

Tabel 4. Data Alternatif Maskapai

\begin{tabular}{lcccccccc}
\hline Alternatif & C1 & C2 & C3 & C4 & C5 & C6 & C7 & C8 \\
\hline Batik Air & 80 & 35 & 35 & 35 & 624.645 & 35 & 35 & 30 \\
Citilink & 70 & 25 & 35 & 40 & 512.152 & 40 & 40 & 30 \\
Garuda Indonesia & 80 & 40 & 40 & 40 & 851.212 & 45 & 40 & 40 \\
Indonesia AirAsia & 65 & 20 & 30 & 35 & 421.969 & 40 & 40 & 30 \\
Lion Air & 60 & 20 & 25 & 30 & 449.352 & 30 & 30 & 20 \\
NAM Air & 60 & 15 & 25 & 35 & 430.914 & 35 & 40 & 35 \\
\hline
\end{tabular}

Berdasarkan data alternatif yang telah ditentukan sebelumnya, perhitungan berikut menunjukkan contoh penghitungan nilai normalisasi untuk alternatif Batik Air menggunakan MOORA. Untuk 
alternatif berikutnya, gunakan rumus yang sama untuk menghasilkan nilai normalisasi alternatif yang ditunjukkan pada Tabel 5.

$$
\begin{aligned}
& X^{*}{ }_{i j}=\frac{x_{i j}}{\sqrt{\left[\sum_{j=1}^{m}\left(x_{i j}\right)^{2}\right]}} \\
& X^{*}{ }_{11}=\frac{80}{\sqrt{\left[(80)^{2}+(70)^{2}+(80)^{2}+(65)^{2}+(60)^{2}+(60)^{2}\right]}}=0.4688 \text {; } \\
& X^{*}{ }_{12}=\frac{35}{\sqrt{\left[(35)^{2}+(25)^{2}+(40)^{2}+(20)^{2}+(20)^{2}+(15)^{2}\right]}}=0.5232 \text {; } \\
& X^{*}{ }_{13}=\frac{35}{\sqrt{\left[(35)^{2}+(35)^{2}+(40)^{2}+(30)^{2}+(25)^{2}+(25)^{2}\right]}}=0,4445 \text {; } \\
& X^{*}{ }_{14}=\frac{35}{\sqrt{\left[(35)^{2}+(40)^{2}+(40)^{2}+(35)^{2}+(30)^{2}+(35)^{2}\right]}}=0,3969 \text {; } \\
& X^{*}{ }_{15}=\frac{624.645}{\sqrt{\left[(624.645)^{2}+(512.152)^{2}+(851.212)^{2}+(421.969)^{2}+(449.352)^{2}+(430.914)^{2}\right]}}=0.4482 \text {; } \\
& X^{*}{ }_{16}=\frac{35}{\sqrt{\left[(35)^{2}+(40)^{2}+(45)^{2}+(40)^{2}+(30)^{2}+(35)^{2}\right]}}=0,3780 \\
& X^{*}{ }_{17}=\frac{35}{\sqrt{\left[(35)^{2}+(40)^{2}+(40)^{2}+(40)^{2}+(30)^{2}+(40)^{2}\right]}}=0,3791 \text {; } \\
& X^{*}{ }_{18}=\frac{30}{\sqrt{\left[(30)^{2}+(30)^{2}+(40)^{2}+(30)^{2}+(20)^{2}+(35)^{2}\right]}}=0,3897
\end{aligned}
$$

Tabel 5. Data Normalisasi Alternatif Maskapai

\begin{tabular}{lllllllll}
\hline Alternatif & C1 & C2 & C3 & C4 & C5 & C6 & C7 & C8 \\
\hline Batik Air & 0,4688 & 0,5232 & 0,4445 & 0,3969 & 0,4482 & 0,3780 & 0,3791 & 0,3897 \\
Citilink & 0,4102 & 0,3737 & 0,4445 & 0,4536 & 0,3674 & 0,4320 & 0,4332 & 0,3897 \\
Garuda Indonesia & 0,4688 & 0,5979 & 0,5080 & 0,4536 & 0,6107 & 0,4860 & 0,4332 & 0,5197 \\
Indonesia AirAsia & 0,3809 & 0,2990 & 0,3810 & 0,3969 & 0,3027 & 0,4320 & 0,4332 & 0,3897 \\
Lion Air & 0,3516 & 0,2990 & 0,3175 & 0,3402 & 0,3224 & 0,3240 & 0,3249 & 0,2598 \\
NAM Air & 0,3516 & 0,2242 & 0,3175 & 0,3969 & 0,3092 & 0,3780 & 0,4332 & 0,4547 \\
\hline
\end{tabular}

Setelah didapatkan nilai normalisasi alternatif, perhitungan nilai preferensi pada MOORA dilanjutkan pada perhitungan nilai optimasi. Perhitungan berikut menunjukkan nilai preferensi yang dihitung menggunakan FUCOM-MOORA pada alternatif Batik Air. Untuk alternatif berikutnya, gunakan rumus yang sama untuk menghasilkan nilai preferensi penentuan maskapai favorit menggunakan FUCOM-MOORA yang ditunjukkan pada Tabel 6 .

$$
\begin{aligned}
& y^{*}{ }_{j}=\sum_{j=1}^{g} w_{j} x^{*}{ }_{i j}-\sum_{i=g+1}^{n} w_{j} x^{*}{ }_{i j} \\
& y^{*}{ }_{1}=\Sigma\left[\begin{array}{c}
(0,15953 \times 0,4688) ;(0,11728 \times 0,5232) ; \\
(0,11110 \times 0,4445) ;(0,12093 \times 0,3969) ; \\
(0,12586 \times 0,3780) ;(0,10643 \times 0,3791) ;
\end{array}\right]-(0,17337 \times 0,4482) \\
& y^{*}{ }_{1}=[0,07478+0,06136+0,04938+0,04800+0,04757+0,04034+0,03333]-0,07769 \\
& y^{*}{ }_{1}=0,35477-0,07769=0,27707
\end{aligned}
$$

Tabel 6. Nilai Preferensi Penentuan Maskapai Favorit

\begin{tabular}{lll}
\hline Alternatif & Nilai Preferensi & Peringkat \\
\hline Garuda Indonesia & 0,30204 & Peringkat ke-1 \\
Citilink & 0,28360 & Peringkat ke-2 \\
Batik Air & 0,27707 & Peringkat ke-3 \\
Indonesia AirAsia & 0,26747 & Peringkat ke-4 \\
NAM Air & 0,24462 & Peringkat ke-5 \\
Lion Air & 0,20925 & Peringkat ke-6 \\
\hline
\end{tabular}


Nilai Preferensi Penentuan Maskapai Favorit Menggunakan FUCOMMOORA

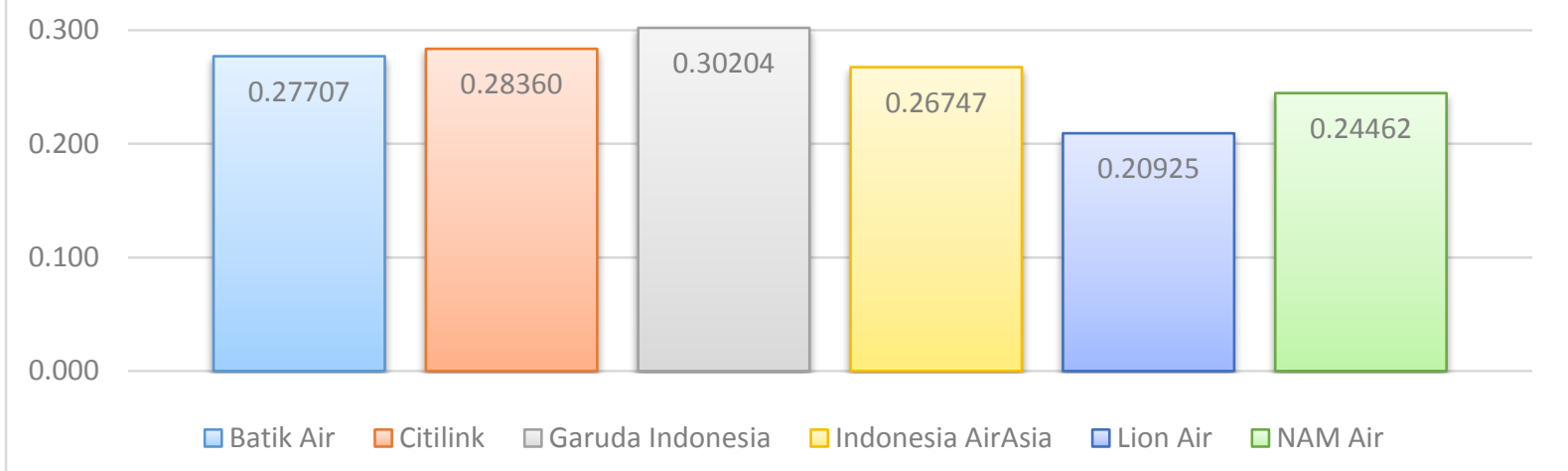

\section{Gambar 5. Grafik Nilai Preferensi Penentuan Maskapai Favorit Menggunakan FUCOM- MOORA}

Grafik pemeringkatan nilai preferensi penentuan maskapai favorit menggunakan FUCOMMOORA ditunjukkan pada Gambar 5. Hasil dari perhitungan menggunakan FUCOM-MOORA menunjukkan bahwa Garuda Indonesia menjadi maskapai terfavorit di Indonesia, di susul dengan Citilink, Batik Air, Indonesia AirAsia, NAM Air dan Lion Air menjadi posisi terakhir berdasarkan data yang diujikan. Pengujian terhadap perangkingan pada FUCOM-MOORA dilakukan menggunakan analisis konsistensi, dengan tujuan mencari seberapa konsisten suatu pemeringkatan alternatif terhadap perubahan kondisi pembobotan kriteria. Terdapat 17 skenario yang ditawarkan untuk menghitung analisis konsistensi, yang ditampilkan pada Tabel 7.

Tabel 7. Skenario Pembobotan Antar Kriteria untuk Analisis Konsistensi Ternormalisasi

\begin{tabular}{lllllllll}
\hline Kriteria & $\mathrm{C} 1$ & $\mathrm{C} 2$ & $\mathrm{C} 3$ & $\mathrm{C} 4$ & $\mathrm{C} 5$ & $\mathrm{C} 6$ & $\mathrm{C} 7$ & $\mathrm{C} 8$ \\
\hline Skenario Awal & 0,15953 & 0,11728 & 0,11110 & 0,12093 & 0,17337 & 0,12586 & 0,10643 & 0,08551 \\
Skenario $w_{1}+0,5$ & 0,43969 & 0,07819 & 0,07406 & 0,08062 & 0,11558 & 0,08391 & 0,07095 & 0,05701 \\
Skenario $w_{2}+0,5$ & 0,10635 & 0,41152 & 0,07406 & 0,08062 & 0,11558 & 0,08391 & 0,07095 & 0,05701 \\
Skenario $w_{3}+0,5$ & 0,10635 & 0,07819 & 0,40740 & 0,08062 & 0,11558 & 0,08391 & 0,07095 & 0,05701 \\
Skenario $w_{4}+0,5$ & 0,10635 & 0,07819 & 0,07406 & 0,41395 & 0,11558 & 0,08391 & 0,07095 & 0,05701 \\
Skenario $w_{5}+0,5$ & 0,10635 & 0,07819 & 0,07406 & 0,08062 & 0,44891 & 0,08391 & 0,07095 & 0,05701 \\
Skenario $w_{6}+0,5$ & 0,10635 & 0,07819 & 0,07406 & 0,08062 & 0,11558 & 0,41724 & 0,07095 & 0,05701 \\
Skenario $w_{7}+0,5$ & 0,10635 & 0,07819 & 0,07406 & 0,08062 & 0,11558 & 0,08391 & 0,40428 & 0,05701 \\
Skenario $w_{8}+0,5$ & 0,10635 & 0,07819 & 0,07406 & 0,08062 & 0,11558 & 0,08391 & 0,07095 & 0,39034 \\
Skenario $w_{1}+1$ & 0,57977 & 0,05864 & 0,05555 & 0,06046 & 0,08668 & 0,06293 & 0,05321 & 0,04276 \\
Skenario $w_{2}+1$ & 0,07977 & 0,55864 & 0,05555 & 0,06046 & 0,08668 & 0,06293 & 0,05321 & 0,04276 \\
Skenario $w_{3}+1$ & 0,07977 & 0,05864 & 0,55555 & 0,06046 & 0,08668 & 0,06293 & 0,05321 & 0,04276 \\
Skenario $w_{4}+1$ & 0,07977 & 0,05864 & 0,05555 & 0,56046 & 0,08668 & 0,06293 & 0,05321 & 0,04276 \\
Skenario $w_{5}+1$ & 0,07977 & 0,05864 & 0,05555 & 0,06046 & 0,58668 & 0,06293 & 0,05321 & 0,04276 \\
Skenario $w_{6}+1$ & 0,07977 & 0,05864 & 0,05555 & 0,06046 & 0,08668 & 0,56293 & 0,05321 & 0,04276 \\
Skenario $w_{7}+1$ & 0,07977 & 0,05864 & 0,05555 & 0,06046 & 0,08668 & 0,06293 & 0,55321 & 0,04276 \\
Skenario $w_{8}+1$ & 0,07977 & 0,05864 & 0,05555 & 0,06046 & 0,08668 & 0,06293 & 0,05321 & 0,54276 \\
\hline
\end{tabular}

Berdasarkan skenario tersebut, dilakukan perhitungan ulang terhadap nilai preferensi, pemeringkatan pada FUCOM-MOORA dan dicari rata-rata peringkat dari seluruh skenario. Hasil sebaran peringkat untuk menghitung analisis konsistensi serta rata-rata sebaran peringkat ditampilkan pada Tabel 8. 
Tabel 8. Nilai Preferensi Penentuan Maskapai Favorit

\begin{tabular}{llllllll}
\hline Alternatif & \multicolumn{3}{l}{ Jumlah Peringkat } & & & & GeoMean \\
& 1 & 2 & 3 & 4 & 5 & 6 & Sebaran Peringkat \\
\hline Batik Air & - & 4 kali & 5 kali & 6 kali & 2 kali & - & 3,20541 \\
Citilink & - & 11 kali & 6 kali & - & - & - & 2,30770 \\
Garuda Indonesia & 15 kali & - & - & - & - & 2 kali & 1,23466 \\
Indonesia AirAsia & 2 kali & - & 4 kali & 9 kali & 2 kali & - & 3,26012 \\
Lion Air & - & - & - & 1 kali & 3 kali & 13 kali & 5,67309 \\
NAM Air & - & 2 kali & 2 kali & 1 kali & 10 kali & 2 kali & 4,26254 \\
\hline
\end{tabular}

Berdasarkan analisis konsistensi menunjukkan dari 17 skenario berbeda terhadap modifikasi pembobotan kriteria, menunjukkan bahwa Garuda Indonesia tetap menjadi favorit pelanggan untuk pemilihan Maskapai di Indonesia. Dari 17 pengujian yang dilakukan Garuda Indonesia mencapai 15 kali peringkat pertama dan 2 kali peringkat keenam. Hal ini disebabkan pada 2 kali pengujian tersebut, menitik beratkan pada faktor harga. Harga yang dipatok oleh Garuda Indonesia memang paling mahal diantara pesaingnya, namun faktor lainnya seperti kenyamanan, kebersihan, pelayanan pelanggan dan lainnya memiliki nilai yang lebih baik dibandingkan dengan pesaing. Penelitian ini menunjukkan bahwa dari sampel narasumber yang dipilih menunjukkan bahwa harga menjadi pilihan utama dalam pemilihan maskapai favoritnya. Garuda Indonesia merupakan maskapai favorit berdasarkan pilihan narasumber yang dijadikan sampling.

\section{Kesimpulan}

Penelitian ini telah berhasil mengimplementasikan FUCOM-MOORA dalam penentuan maskapai favorit di Indonesia berdasarkan narasumber yang dilakukan sampling, dengan menggunakan 8 kriteria dan 6 alternatif yang diujikan. Pada perhitungan pembobotan kriteria menggunakan FUCOM menunjukkan bahwa faktor harga (C5) merupakan faktor yang paling diperhitungkan oleh narasumber, disusul dengan faktor kenyamanan (C1), kebersihan (C6) dan pelayanan pelanggan (C4). Perhitungan menggunakan FUCOM-MOORA menunjukkan bahwa Garuda Indonesia menjadi maskapai favorit di Indonesia dengan nilai preferensi sebesar 0,30204, disusul dengan Citilink menjadi maskapai favorit kedua, Batik Air menempati peringkat ketiga, dan berturut-turut selanjutnya dicapai oleh Indonesia AirAsia, NAM Air dan Lion Air menempati peringkat terakhir dari alternatif yang diujikan. Ketika analisis konsistensi dilakukan, Garuda Indonesia tetap stabil menjadi pilihan pertama dengan menempati 15 kali peringkat teratas dari 17 pengujian dengan rata-rata sebaran peringkat sebesar 1,23466.

\section{Ucapan Terima Kasih}

Terimakasih penulis ucapkan kepada STMIK STIKOM Indonesia, atas pendanaan dalam program hibah Penelitian Dosen Mahasiswa tahun pelaksanaan 2021, dengan nomor kontrak 07/04/LPPM/PDM/V/2021. Terimakasih kepada Tim Editorial Jurnal Sistem Informasi (SISTEMASI) yang telah memberikan kesempatan untuk penulis dapat menerbitkan artikel ini..

\section{Referensi}

[1] T. Santia, "Rentetan Kejadian Pesawat Maskapai Nasional di Awal 2021, Masalah Mesin hingga Pecah Ban," Liputan 6, Mar. 12, 2021. https://www.liputan6.com/bisnis/read/4504854/rentetankejadian-pesawat-maskapai-nasional-di-awal-2021-masalah-mesin-hingga-pecah-ban

[2] W. S. Widodo, "Airbus Umumkan Rugi Rp 18,8 Triliun Gegara Pandemi Corona," Detik.com, Feb. 23, 2021. https://travel.detik.com/travel-news/d-5401132/airbus-umumkan-rugi-rp-188triliun-gegara-pandemi-corona

[3] J. Dalle, "Pandemi Corona dan Drama "Terra Incognita," Detik.com, Nov. 16, 2020. https://news.detik.com/kolom/d-5256888/pandemi-corona-dan-drama-terra-incognita

[4] D. Kuswaraharja, "Cara Dapatkan Rapid Test Antigen Gratis di 5 Maskapai," Detik.com, Mar. 08, 2021. https://travel.detik.com/travel-news/d-5485219/cara-dapatkan-rapid-test-antigen-gratisdi-5-maskapai 
[5] N. Indriyani, E. Ali, U. Rio, and R. Rahmaddeni, "Menentukan Kualitas Pelayanan Maskapai Penerbangan Domestik Dengan Menggunakan Metode Naïve Bayes:," SATIN, vol. 6, no. 1, pp. 37-44, Jun. 2020, doi: 10.33372/stn.v6i1.605.

[6] S. Seimahuira, "Implementasi Datamining dalam Menentukan Destinasi Unggulan Berdasarkan Online Reviews TripAdvisor Menggunakan Alogoritma K-Means," Jurnal Technologia, vol. 12, no. 1, pp. 53-58, 2021.

[7] N. K. A. P. Sari, "Implementation of the AHP-SAW Method in the Decision Support System for Selecting the Best Tourism Village," Jurnal Teknik Informatika C.I.T Medicom, vol. 13, no. 1, pp. 22-31, Mar. 2021.

[8] G. S. Mahendra and P. G. S. C. Nugraha, "Komparasi Metode AHP-SAW dan AHP-WP pada SPK Penentuan E-Commerce Terbaik di Indonesia Comparison of AHP-SAW and AHP-WP Methods on DSS to Determine the Best E-Commerce in Indonesia," Jurnal Sistem dan Teknologi Informasi (JUSTIN), vol. 08, no. 4, pp. 346-356, 2020, doi: 10.26418/justin.v8i4.42611.

[9] G. S. Mahendra and E. Hartono, "Komparasi Analisis Konsistensi Metode AHP-MAUT dan AHP-PM pada SPK Penempatan Siswa OJT," Jurnal Teknologi Informasi Informasi dan Komputer, vol. 7, no. 2, 2021.

[10] I. Badi and A. Abdulshahed, "Ranking the Libyan airlines by using Full Consistency Method (FUCOM) and Analytical Hierarchy Process (AHP)," Operational Research in Engineering Sciences: Theory and Applications, vol. 2, no. 1, pp. 1-14, 2019, doi: 10.31181/oresta1901001b.

[11] D. Pamučar, Ž. Stević, and S. Sremac, "A new model for determiningweight coefficients of criteria in MCDM models: Full Consistency Method (FUCOM)," Symmetry, vol. 10, no. 9, pp. 1-22, 2018, doi: 10.3390/sym10090393.

[12] B. Matić et al., "A New Hybrid MCDM Model : Sustainable Supplier Selection in a Construction Company," Symmetry, vol. 11, no. March, pp. 1-24, 2019, doi: 10.3390/sym11030353.

[13] D. Assrani, N. Huda, R. Sidabutar, I. Saputra, and O. K. Sulaiman, "Penentuan Penerima Bantuan Siswa Miskin Menerapkan Metode Multi Objective Optimization on The Basis of Ratio Analysis (MOORA)," Jurnal Riset Komputer (JURIKOM), vol. 5, no. 1, pp. 1-5, 2018.

[14] A. S. R. A. Binjori, H. R. B. Hutapea, M. Syahrizal, and N. Kurniasih, "Sistem Pendukung Keputusan Penentuan Handphone Bekas Terbaik Menggunakan Metode Multi-Objective Optimization on The Basis of Ratio Analysis (MOORA)," Jurnal Riset Komputer (JURIKOM), vol. 5, no. 1, pp. 61-65, 2018.

[15] W. Brauers, "Location Theory and Multi-Criteria Decision Making: An Application of the MOORA Method," IDEAS, vol. 12, no. 3, pp. 241-252, 2018, doi: 10.5709/ce.1897-9254.275.

[16] G. S. Mahendra, I. W. W. Karsana, and A. A. I. I. Paramitha, "DSS for best e-commerce selection using AHP-WASPAS and AHP-MOORA methods," MATRIX, vol. 11, no. 2, pp. 8194, Jul. 2021, doi: 10.31940/matrix.v11i2.2306.

[17] B. Setiani, "Tanggung Jawab Maskapai Penerbangan Sebagai Penyedia Jasa Penerbangan Kepada Penumpang Akibat Keterlambatan Penerbangan," JHN, vol. 7, no. 3, Feb. 2016, doi: 10.26555/novelty.v7i3.a3930.

[18] I. Setiawan, D. Nusraningrum, and Y. Pahala, "Deregulasi Penerbangan dan Kinerja Perusahaan Penerbangan Niaga Berjadwal di Indonesia," Jurnal Manajemen Transportasi dan Logistik, vol. 2, no. 1, p. 1, Jul. 2017, doi: 10.25292/j.mtl.v2i1.130.

[19] D. Pamučar, Ž. Stević, and S. Sremac, "A new model for determiningweight coefficients of criteria in MCDM models: Full Consistency Method (FUCOM)," Symmetry, vol. 10, no. 9, pp. 1-22, 2018, doi: 10.3390/sym10090393.

[20] Ž. Stević and N. Brković, "A Novel Integrated FUCOM-MARCOS Model for Evaluation of Human Resources in a Transport Company," Symmetry, vol. 4, no. 1, p. 4, 2020, doi: 10.3390/logistics4010004.

[21] Ž. Stević, B. Miciić, D. Lukić, M. Tomašević, and S. Sremac, "Supplier Selection for Distribution of Finished Products: Combined FUCOM-MABAC Model," in The Seventh International Confrence Transport and Logistics, 2019, no. December, pp. 35-40.

[22] Y. Sa'adati, S. Fadli, and K. Imtihan, "Analisis Penggunaan Metode AHP dan MOORA untuk Menentukan Guru Berprestasi sebagai Ajang Promosi Jabatan," Publikasi Jurnal \& Penelitian Teknik Informatika, vol. 3, no. 1, pp. 82-90, 2018. 
[23] U. K. Mandal and B. Sarkar, "Selection of Best Intelligent Manufacturing System (IMS) Under Fuzzy MOORA Conflicting MCDM Environment," IJETAE (International Journal of Emerging Technology and Advanced Engineering), vol. 2, no. 9, pp. 301-310, 2012.

[24] I. G. Hendrayana and G. S. Mahendra, "Perancangan Metode AHP-MOORA Pada Sistem Pendukung Keputusan Pemilihan Paket Wisata," Prosiding Seminar Nasional Pendidikan Teknik Informatika (SENAPATI) Ke-10, vol. 1, no. 1, pp. 143-149, 2019.

[25] R. Wirth and J. Hipp, "CRISP-DM: Towards a Standard Process Model for Data Mining," Semantic Scholar, vol. 1, no. 24959, pp. 1-11, 2000.

[26] G. S. Mahendra and I. P. Y. Indrawan, "Metode AHP-TOPSIS Pada Sistem Pendukung Keputusan Penentuan Penempatan Atm," JST (Jurnal Sains dan Teknologi), vol. 9, no. 2, pp. 130-142, 2020, doi: 10.23887/jst-undiksha.v9i2.24592.

[27] E. Exenberger and J. Bucko, "Analysis of Online Consumer Behavior - Design of CRISP-DM Process Model," AOL, vol. 12, no. 3, pp. 13-22, Sep. 2020, doi: 10.7160/aol.2020.120302.

[28] M. A. Rivai, "Analysis of Corona Virus spread uses the CRISP-DM as a Framework: Predictive Modelling," International Journal of Advanced Trends in Computer Science and Engineering, vol. 9, no. 3, pp. 2987-2994, 2020, doi: 10.30534/ijatcse/2020/76932020. 